Available online at https://jurnal.stmikroyal.ac.id/index.php/jurdimas

\title{
PELATIHAN MEMBUAT APLIKASI ANDROID DENGAN ANDROID STUDIO PADA SMP NEGERI 1 TINGGI RAJA
}

\author{
Akmal Nasution ${ }^{* 1}$, Bachtiar Efendi ${ }^{2}$, Iqbal Kamil Siregar ${ }^{2}$ \\ ${ }^{1}$ Program Studi Sistem Informasi, STMIK Royal \\ ${ }^{2}$ Program Studi Sistem Komputer, STMIK Royal \\ Email:*nst.akmal@gmail.com, medo_bakti@gmail.com
}

\begin{abstract}
The community service activity entitled "Training on Making Android Applications with Android Studio at junior high school 1 Tinggi Raja" aims to train existing students at junior high school 1 Tinggi Raja to create an Android application. Moreover, most students must have already had an Android phone, it would be more interesting and fun to be able to make an application on their own cellphone. The method used in this activity is a description and practice. The speaker performs explanations about Android and Android Studio itself, their functions and uses, after that the practice directly uses the Android Studio and how to build it so that it becomes an android file that can be installed on each student's cellphone. Some important points are explained and practiced in this activity, namely the introduction of the Android operating system, the introduction of Android Studio, how to design displays in Android Studio, and how to learn java coding in Android Studio so as to produce an android application.
\end{abstract}

Keywords: android application, android studio, android

\begin{abstract}
Abstrak: Kegiatan pengabdian kepada masyarakat yang diberi judul "Pelatihan Membuat Aplikasi Android dengan Android Studio pada SMPN 1 Tinggi Raja" bertujuan untuk melatih siswa-siswi yang ada pada SMPN 1 Tinggi Raja untuk membuat aplikasi Android. Terlebih lagi para siswa juga pasti sebagian besar sudah memiliki ponsel Android, hal ini akan lebih menarik dan menyenangkan jika dapat membuat aplikasi di ponsel sendiri. Metode yang digunakan dalam kegiatan ini adalah deskripsi dan praktek. Pemateri melakukan penjelasan-penjelasan tentang Android dan Android Studio itu sendiri, fungsi dan kegunaannya, setelah itu praktek langsung menggunakan Android Studio tersebut dan bagaimana cara build nya sehingga menjadi sebuah file android yang dapat dipasang di ponsel masing-masing siswa. Beberapa point penting yang dijelaskan serta dipraktekkan dalam kegiatan ini, yaitu pengenalan sistem operasi Android, pengenalan Android Studio, cara mendesain tampilan di Android Studio, dan bagaimana belajar koding java di Android Studio sehingga menghasilkan sebuah aplikasi android.
\end{abstract}

Kata kunci: aplikasi android, android studio, android 
Jurdimas (Jurnal Pengabdian Kepada Masyarakat) Royal

Vol. 2 No. 1, Jan 2019, hlm. 53 - 58

ISSN 2614-7912 (Print)

DOI: https://doi.org/10.33330/jurdimas.v2i1.321

ISSN 2622-3813 (Online)

Available online at https://jurnal.stmikroyal.ac.id/index.php/jurdimas

\section{PENDAHULUAN}

SMPN 1 Tinggi Raja sebagai salah satu Lembaga pendidikan Formal yang menyelenggarakan jenjang pendidikan menengah pertama (SMP). Salah satu yang menjadi tuntutan bagi SMP saat ini adalah bagaimana agar bisa mencitrakan diri sebagai sekolah yang mampu mencetak siswanya menjadi lulusan yang produktif dan professional.

Tamatan SMPN 1 Tinggi Raja diharapkan dapat diterima di jenjang pendidikan yang lebih tinggi dari tingkat lokal, nasional maupun Internasional. Dengan demikian pencitraan (Brand) SMPN 1 Tinggi Raja menjadi salah satu bagian yang tak kalah pentingnya dalam pengelolaan lembaga yang harus diketahui oleh masyarakat. Orientasi pencitraan SMP diarahkan supaya selalu mendapatkan peluang dan keunggulan kompetitif terutama pada lulusan yang profesional. Untuk dapat melakukan terobosan, maka perlu adanya tanggung jawab bersama menyangkut Sumber Daya Manusia (SDM), untuk itu perlu dilakukan penambahan kemampuan extra terhadap siswa-siswi SMPN 1 Tinggi Raja demi menunjang kebutuhan dunia.

Salah satu mata pelajaran yang ada di SMP adalah TIK. TIK sebagai salah satu mata pelajaran yang diajarkan di SMP yang berhubungan dengan teknologi informasi, diharapkan dapat meningkatkan pengetahuan, keterampilan dan kemampuan siswa dalam bidang teknologi komputer. Mata pelajaran TIK dapat digolongkan sebagai salah satu mata pelajaran yang penting untuk dipelajari karena mengingat pentingnya peranan teknologi informasi sebagai salah satu ilmu terapan, ilmu yang dipakai dalam praktek bisnis. Potensi inilah yang akan mampu menghadapi perkembangan dan tantangan manusia dari masa ke masa. Sehingga siswasiswi mampu menerapkan TIK tersebut di jenjang pendidikan yang lebih tinggi nanti bahkan saat menghadapai dunia kerja nantinya dan salah satu bekal untuk melanjutkan pendidikan ke jenjang yang lebih tinggi.

Saat ini hampir seluruh masyarakat indonesia memiliki smartphone android, bukan hanya sebagai alat komunikasi smartphone ini juga banyak memiliki fungsi tergantung pada aplikasi yang digunakan pada smartphone tersebut, oleh karena itu saat ini banyak masyarakat terutama siswa/siswi ingin memahami bagaimana membangun aplikasi android tersebut. Kelebihan dari android adalah sifatnya yang opensource dan mudah untuk dikembangkan, bahkan oleh siswasiswa SMP. Dengan demikian para siswa SMP ini nantinya dapat membangun dan mengembangkan sebuah aplikasi android dan memasangnya langsung pada perangkat mobilenya masing-masing yang tidak menutup kemungkinan untuk bisa dikomersilkan.

Kondisi ini juga terjadi di SMPN 1 Tinggi Raja. Berdasarkan hasil observasi yang telah penulis lakukan, Penulis memperoleh data bahwa siswa-siswi di kelas XI SMPN 1 Tinggi Raja memiliki minat untuk hal itu. Untuk itu perlu dilakukan pelatihan terhadap siswa-siswi tersebut.

Kegiatan ini selain bertujuan 
Jurdimas (Jurnal Pengabdian Kepada Masyarakat) Royal

Vol. 2 No. 1, Jan 2019, hlm. 53 - 58

ISSN 2614-7912 (Print)

DOI: https://doi.org/10.33330/jurdimas.v2i1.321

ISSN 2622-3813 (Online)

Available online at https://jurnal.stmikroyal.ac.id/index.php/jurdimas

untuk melaksanakan Tri Dharma Perguruan Tinggi berupa Pengabdian Kepada Masyarakat sebagai pengamalan ilmu pengetahuan dosen, bermanfaat juga sebagai wadah kreatifitas dan media pengembangan diri bagi siswa-siswi SMP atau bahkan dapat menjadi referensi bagi yang berminat dalam ilmu Pemrograman Android.

\section{METODE}

Strategi yang digunakan untuk mencapai pemahaman siswa mengenai pelatihan pembuatan aplikasi android tersebut adalah dengan menerapkan dua metode yaitu metode pelatihan dan metode simulasi ipteks.

Metode pelatihan yaitu metode yang digunakan untuk kegiatan yang melibatkan penyuluhan atau penyampaian materi tentang substansi kegiatan yang disertai dengan demonstrasi atau percontohan untuk realisasi dan pelatihan dalam pengoperasian sistem atau peralatan. Dalam kegiatan ini dimulai dari pemaparan sejarah android, dasar pemrograman android, sistem operasi android, versi android dan pemrograman andriod studio.

Metode Simulasi Ipteks yaitu metode yang digunakan untuk kegiatan yang karya utamanya adalah sistem informasi atau sejenisnya. Dalam kegiatan pengabdian ini berarti dilakuakan praktek membuat aplikasi android secara langsung, pelatihan mulai dari cara penginstalan dan pengenalan file-file menu yang ada di Android studio, sehingga teknik Pembuatan Program sederhana, dan siswa menguasai materi yang disampaikan dengan sangat baik.

\section{PEMBAHASAN}

Pembahasan dalam kegiatan pengabdian masyarakat mencakup materi pokok tentang android. Secara garis besar materi bahasan mengenai sistem operasi mobile, android, dan pengembangan aplikasi android dengan android studio yang dijelaskan dibawah ini.

Sistem operasi adalah software utama yang melakukan manajemen dan kontrol terhadap hardware secara langsung serta manajemen dan mengontrol software-software lain sehingga software-software lain tersebut dapat bekerja. Salah satu sistem operasi khususnya untuk perangakat mobile adalah Android. Operating System (OS) Android dibangun berbasis platform Linux yang bersifat opensource, senada dengan Linux, Android juga bersifat Open Source. Dengan nama besar Google dan konsep opensource pada OS Android, tidak membutuhkan waktu lama bagi android untuk bersaing dan menyisihkan Mobile OS lainnya seperti Symbian, Windos Mobile, Blackberry dan iOS. Sistem operasi Android sendiri mempunyai beberapa versi, yang terbaru adalah versi 9.0 dengan kode name Pie.

Membuat Aplikasi Android menggunakan Android Studio yang mendukung dua bahasa pemrograman, yaitu java dan kotlin. Android menggunakan bahasa XML untuk scripting layout nya. Beberapa istilah yang populer dalam pemrograman android seperti Activity, Fragment merupakan container untuk User Interface (UI) dalam pemrograman android. Sebuah Aplikasi Android terbangun dari satu atau beberapa Activity, sementara itu satu activity 
Jurdimas (Jurnal Pengabdian Kepada Masyarakat) Royal

Vol. 2 No. 1, Jan 2019, hlm. 53 - 58

ISSN 2614-7912 (Print)

DOI: https://doi.org/10.33330/jurdimas.v2i1.321

ISSN 2622-3813 (Online)

Available online at https://jurnal.stmikroyal.ac.id/index.php/jurdimas

dapat terdiri dari beberapa Frament. Sistem pesan utama yang menjalankan Android disebut Intents. Intent terdiri dari action yang harus dijalankan (Tampil, Ubah, Dial, dan lain-lain) dan data. Intent digunakan untuk memulai aktivitas dan komunikasi antar bagian dari sistem Android. Suatu aplikasi dapat mengirimkan atau menerima intent.

Android Studio yang merupakan Lingkungan Pengembangan Terpadu Integrated Development Environment (IDE) untuk pengembangan aplikasi Android, berdasarkan IntelliJ IDEA. Selain merupakan editor kode IntelliJ dan alat pengembang yang berdaya guna, Android Studio menawarkan fitur lebih banyak untuk meningkatkan produktivitas saat membuat aplikasi Android, misalnya sistem versi berbasis Gradle yang fleksibel, emulator yang cepat dan kaya fitur, lingkungan yang menyatu untuk pengembangan bagi semua perangkat Android, instant Run untuk mendorong perubahan ke aplikasi yang berjalan tanpa membuat APK baru, template kode dan integrasi GitHub untuk membuat fitur aplikasi yang sama dan mengimpor kode contoh, alat pengujian dan kerangka kerja yang ekstensif, alat Lint untuk meningkatkan kinerja, kegunaan, kompatibilitas versi, dan masalahmasalah lain, dukungan $\mathrm{C}++$ dan NDK, dukungan bawaan untuk Google Cloud Platform, mempermudah pengintegrasian Google Cloud Messaging dan App Engine.

Tahap selanjutnya setelah pemaparan materi adalah praktik langsung. Untuk mengimplementasikan program aplikasi yang telah dirancang, maka diperlukan sebuah alat bantu berupa komputer, yang mana untuk mengoperasikan komputer itu sendiri yang memerlukan tiga buah komponen pendukung seperti hardware, software, dan brainware. Pembuatan proyek android sederhana dapat dilihat pada gambar berikut.

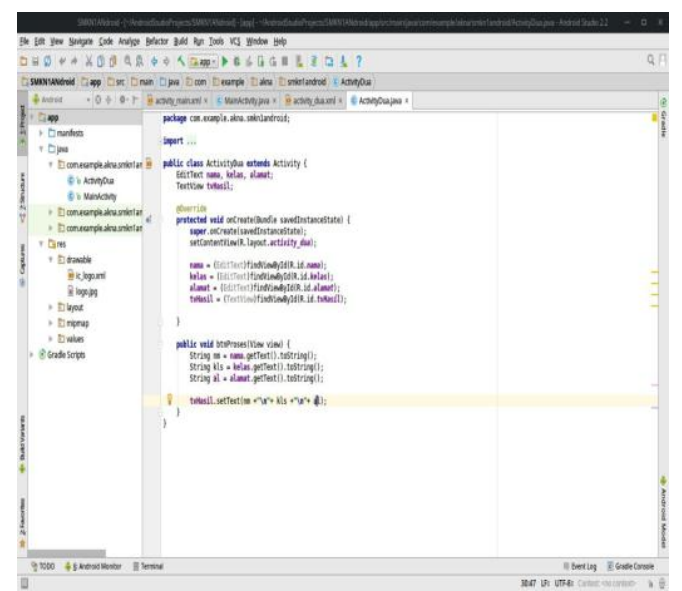

\section{Gambar 1 Halaman Kode Java Android Proyek}

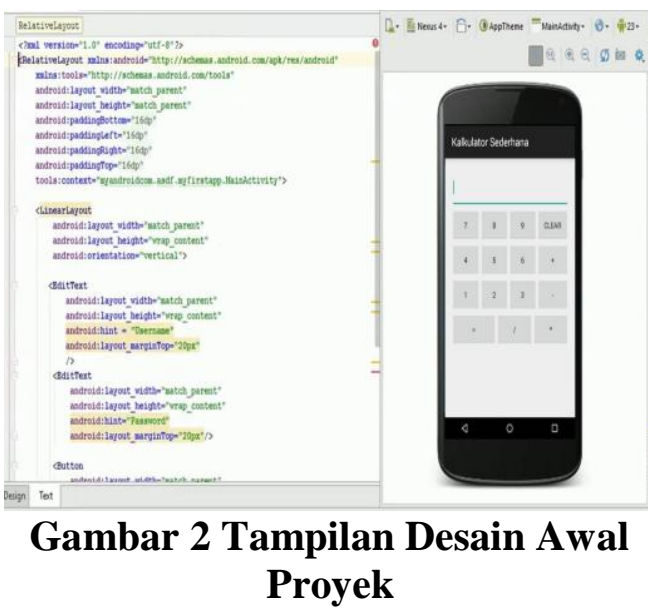

Setelah proses pembuatan proyek aplikasi sederhana selesai, proyek di build sehingga diperoleh sebuah file bereksetensi apk. File ini nantinya yang akan dipasang ke perangkat android masing-masing. Perhatikan gambar 3 yang merupakan tampilan aplikasi saat diinstal di smartphone android. 
Jurdimas (Jurnal Pengabdian Kepada Masyarakat) Royal

Vol. 2 No. 1, Jan 2019, hlm. 53 - 58

DOI: https://doi.org/10.33330/jurdimas.v2i1.321

Available online at https://jurnal.stmikroyal.ac.id/index.php/jurdimas

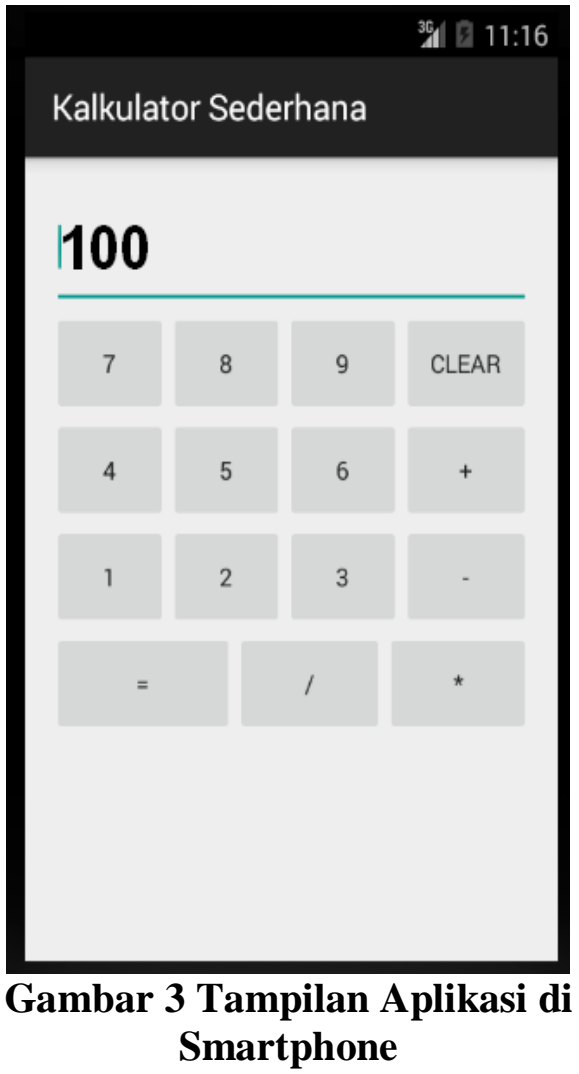

Kegiatan yang berlangsung selama 2 hari yang dimulai dengan pemaparan materi di hari pertama dan pelatihan praktik pembuatan aplikasi android dihari kedua didokumentasikan dalam foto-foto sebagai berikut.

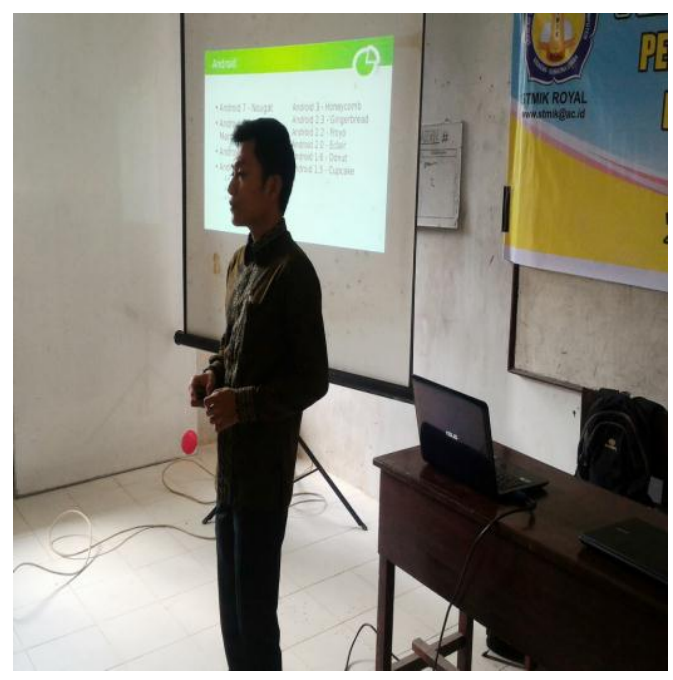

Gambar 4 Pemberian Materi

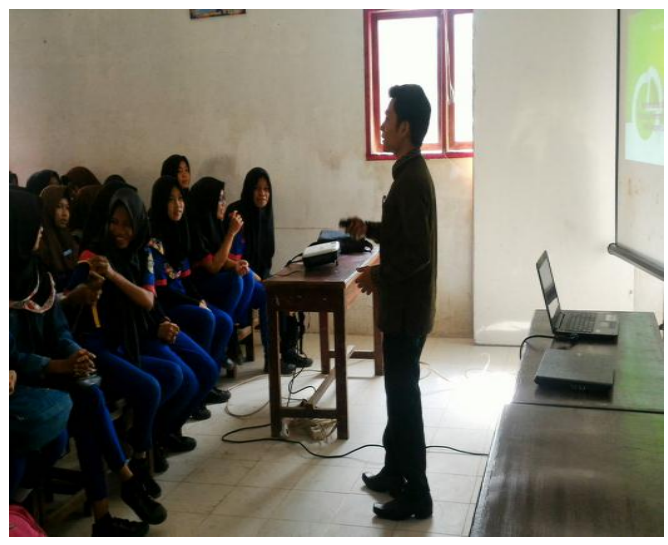

Gambar 5 Pemberian Materi

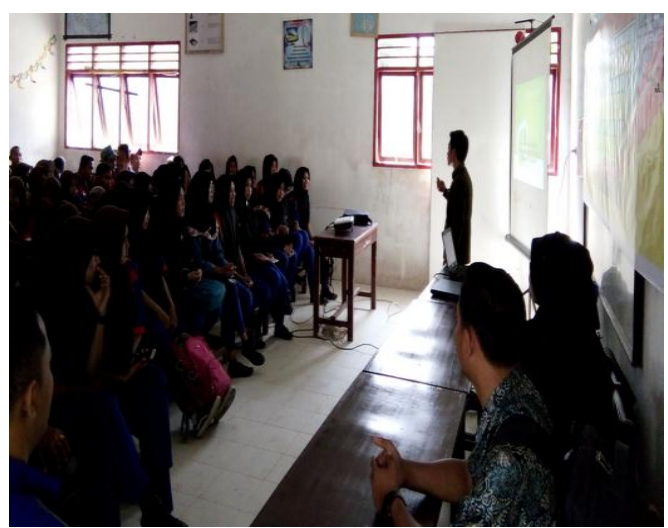

Gambar 6 Sesi Tanya Jawab

\section{SIMPULAN}

Berdasarkan hasil pelaksanaan kegiatan yang telah dilakukan, dapat ditarik kesimpulan bahwa dengan adanya pelatihan Android ini siswa dapat mengembangkan minatnya, siswa juga mendapatkan ilmu baru dan teknik baru dalam ilmu Mobile Android, selain itu siswa dapat melihat ada celah dalam dunia usaha seraya melanjutkan kejenjang pendidikan yang lebih tinggi. Hasilnya melalui kuisioner yang dibagikan, menunjukkan bahwa pemahaman mengenai pembuatan aplikasi android para peserta pelatihan mengalami peningkatan selama dua hari kegiatan berjalan. 
Jurdimas (Jurnal Pengabdian Kepada Masyarakat) Royal

Vol. 2 No. 1, Jan 2019, hlm. 53 - 58

ISSN 2614-7912 (Print)

DOI: https://doi.org/10.33330/jurdimas.v2i1.321

ISSN 2622-3813 (Online)

Available online at https://jurnal.stmikroyal.ac.id/index.php/jurdimas

\section{UCAPAN TERIMA KASIH}

Ucapan terima kasih disampaikan kepada semua kalangan yang terlibat dalam kegiatan pengabdian ini. Kepada Kepala Sekolah SMPN 1 Tinggi Raja yang telah memberikan izin dan tempat untuk mengadakan pengabdian dan kepada ketua yayasan STMIK Royal kisaran yang telah bersedia memberikan dana untuk kelancaran kegiatan pengabdian masyarakat ini. Tidak lupa pula kepada LPPM STMIK Royal dan dosen-dosen lainnya yang terlibat sehingga kegiatan pengabdian masyarakat ini berjalan sebagaimana mestinya.

\section{DAFTAR PUSTAKA}

Kumar, Bimal Aklesh, and Priya Mohite. "Usability of mobile learning applications: a systematic literature review." Journal of Computers in Education 5.1 (2018): 1-17.

Nasution, Akmal. "Perancangan Aplikasi Push Notification Berbasis

Android." JURTEKSI 4, no. 2 (2018): 149-154.

Suryadi, Agus, Akmal Nasution, and Eka Lia Febrianti. "Pengenalan Dan Pelatihan Bahasa Pemograman Android Pada Siswa SMK Negeri 1 Air Joman - Kisaran." Jurdimas (Jurnal Pengabdian Kepada Masyarakat) Royal 2, no. 1 (2018): 1-4.

Siddik, Mohd, and Akmal Nasution. "Teknologi Push Notifikasi Berbasis Android Untuk Informasi Perkuliahan (Studi Kasus: STMIK Royal Kisaran)."
In Seminar Nasional Royal (SENAR), vol. 1, no. 1, pp. 4144. 2018. 